
Not for reproduction, distribution or commercial use.

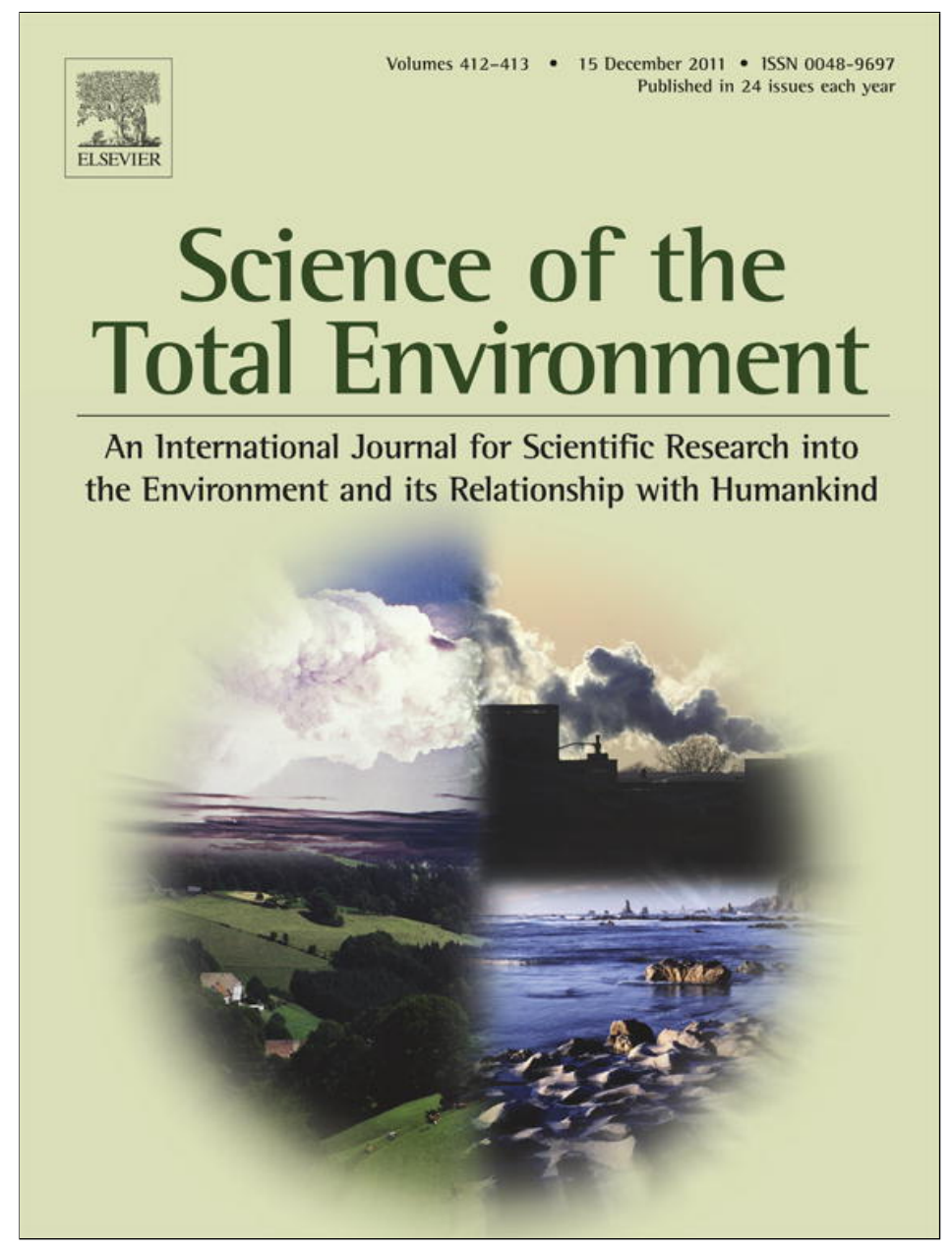

This article appeared in a journal published by Elsevier. The attached copy is furnished to the author for internal non-commercial research and education use, including for instruction at the authors institution and sharing with colleagues.

Other uses, including reproduction and distribution, or selling or licensing copies, or posting to personal, institutional or third party websites are prohibited.

In most cases authors are permitted to post their version of the article (e.g. in Word or Tex form) to their personal website or institutional repository. Authors requiring further information regarding Elsevier's archiving and manuscript policies are encouraged to visit:

http://www.elsevier.com/copyright 


\title{
Microbiological and meteorological analysis of two Australian dust storms in April 2009
}

\author{
Natalie Lim ${ }^{\mathrm{a}, 1}$, Chris I. Munday ${ }^{\mathrm{a}}$, Gwen E. Allison ${ }^{\mathrm{a}, \mathrm{b}}$, , Tadhg O'Loingsigh ${ }^{\mathrm{c}, 2}$, \\ Patrick De Deckker ${ }^{\mathrm{d}}$, Nigel J. Tapper ${ }^{\mathrm{c}}$ \\ a Research School of Biology, The Australian National University, Canberra, ACT 0200, Australia \\ ${ }^{\mathrm{b}}$ ANU Medical School, The Australian National University, Canberra, ACT 0200, Australia \\ c School of Geography and Environmental Science, Monash University, Clayton, Victoria 3800, Australia \\ ${ }^{\mathrm{d}}$ Research School of Earth Sciences, The Australian National University, Canberra, ACT 0200, Australia
}

\section{A R T I C L E I N F O}

\section{Article history:}

Received 28 June 2011

Received in revised form 14 October 2011

Accepted 14 October 2011

Available online 12 November 2011

\section{Keywords:}

Aeolian dust

Bioaerosols

Atmospheric bacteria

Microbial ecology

Bacillus

Pseudomonas

\begin{abstract}
A B S T R A C T
Dust is an important source of bioaerosols including bacteria. In this study, the microbiology and meteorology of specific dust storms in Australia were investigated. The samples were collected from two dust events in April 2009 that were characterised by intense cold fronts that entrained dust from the highly erodible and droughtstricken Mallee and Riverina regions of Victoria and central NSW. In the first storm, the dust travelled eastward over Canberra and Sydney, and in the second storm, the dust travelled east/southeastward over Canberra and Melbourne. Rain fell on both cities during the second dust storm. Dust and rain samples were collected, cultured, and the composition compared using polymerase chain reaction denaturing gradient gel electrophoresis (PCRDGGE). Multiple bands were evident on DGGE indicative of a diverse microflora, and identification of several bands confirmed the presence of multiple genera and species representing three phyla. Numerous bands represented Bacillus species, and these were present in multiple dust samples collected from both Canberra and Melbourne. Interestingly, the microflora present in rain samples collected in Canberra during the second dust storm was quite different and the DGGE banding patterns from these samples clustered separately to most dust samples collected at the same time. Identification of several DGGE bands and PCR products from these rain samples indicated the presence of Pseudomonas species. These results indicate that Australian dust and rain have a diverse microflora and highlights the contribution of dust events to the distribution of microbes in the environment.

(c) 2011 Elsevier B.V. All rights reserved.
\end{abstract}

\section{Introduction}

Dust storms are responsible for approximately $2000 \mathrm{Mt}$ of soil dust emissions per year into the global atmosphere (Shao et al., 2011). The three largest contributors of global dust are the African (Sahara-Sahel region), Asian (Gobi and Takla Makan Deserts) and central Australian dust systems (Kellogg and Griffin, 2006). Griffin's group has extensively investigated the culturable microflora of African dust at its source in Mali (Kellogg et al., 2004) and at sites of deposition including the Caribbean (Griffin et al., 2001; Griffin et al., 2003) and Mediterranean Seas (Griffin et al., 2007). Several bacterial genera, such as Bacillus, Arthrobacter, Agrococcus, Staphylococcus, and Kocuria, were collected from multiple locations and it is not clear whether they

Corresponding author at: Research School of Biology, The Australian National University, Canberra, ACT 0200, Australia. Tel.: +612 6125 4795; fax: +61261250313. E-mail address: gwen.allison@anu.edu.au (G.E. Allison).

${ }^{1}$ Current address: Norwegian University of Life Sciences (UMB), The Department of Chemistry, Biotechnology and Food Science (IKBM), P.O. Box 5003, 1432 Ås, Norway.

${ }^{2}$ Current address: Atmospheric Environment Research Centre, Griffith School of Environment, Griffith University, Brisbane, QLD 4111, Australia. originate from the source or are "cosmopolitan" in nature, being ubiquitous in the environment. Characterisation of the microflora of dust originating in the Takla Makan is also an area of current research. Relative to the dust of African origin, these samples have reduced bacterial diversity, yet members of the cosmopolitan genera Bacillus and Staphylococcus are frequently isolated (Hua et al., 2007; Kakikawa et al., 2008; Maki et al., 2010; Maki et al., 2008). It is not known if this reflects microbial differences in the sources of the dust and/or differences in sample collection and culturing conditions. (Griffin and Kellogg, 2004)

The above studies reflect increased interest worldwide in characterising the biological component of dust, including the bacteria, fungi, and pollen associated with these emissions. These studies have clearly shown that dust is a rich source of microorganisms, and it has been proposed that this biological component of dust could play an important role in distribution of microorganisms and associated diseases such as human respiratory infections and allergens, and fungal infections in plants (reviewed by Griffin and Kellogg, 2004). Increasing transfer of African dust to the Caribbean has corresponded with increased coral bleaching which may be attributable to the microorganisms transported by the dust and/or other nutrients and factors associated with its deposition in the ocean (Shinn et al., 
2000). While the implications of the microbiological component of dust remain to be fully elucidated, dust is also an important source of micronutrients and minerals in the rainforests of Hawaii and the Amazon (Garrison et al., 2003).

The Lake Eyre Basin (LEB) region of central Australia (Fig. 1) is the major dust source for the continent (McTainsh and Strong, 2007) and the primary dust contributor to the Southern Hemisphere, emitting $5.6 \%$ of the global dust total (Tanaka and Chiba, 2006). This region has several similarities with the well-studied Saharan region - mainly low precipitation combined with excessive evaporation, extreme temperatures and indirect human activity (grazing of livestock). Both areas are also large inland drainage basins. Two major dust paths have been identified from the LEB (McTainsh and Strong, 2007): a southeast dust path that exits the southeast of the Australian continent towards the Tasman Sea and New Zealand; and a northwest dust path that exits the northwest of the continent, passing over the Northwest Cape and into the Indian Ocean. These paths are associated with pre-frontal northwest and post-frontal southeast airflows, respectively.

To our knowledge, there is only one publication to date which reports on the microflora of Australian dust (De Deckker et al., 2008). Preliminary sequencing of 48 clones from their Escherichia coli 16S rRNA library identified 39 different operational taxonomic units (OTU) belonging mainly to Proteobacteria, Bacteriodetes, and Firmicutes phyla of soil origin; no pathogens were identified in the analyses. These samples were collected during a dust storm in Canberra on October 22-23, 2002 , where it was estimated that $6 \mathrm{~g} / \mathrm{m}^{2}$ of airborne dust fell overnight during the height of the storm, and was accompanied by rain. Meteorological reports of the storm reveal that it was " $2,400 \mathrm{~km}$ long, up to
$400 \mathrm{~km}$ wide, and 1.5-2.2 km in height" making it the largest reported dust storm in Australia to that time (McTainsh et al., 2005). Another historic dust storm occurred from Sept 22-24, 2009. The October 2002 and September 2009 dust storms both occurred as a result of powerful cold fronts sweeping eastwards across the LEB and the Riverina region of New South Wales (NSW) (Fig. 1). Strong pre-frontal north- and northwest winds carried dust along the southeast dust path, while postfrontal southwest winds pushed dust towards the east and northeast coast of Australia. Both of these storms resulted from an extended drought in central and southern Australia. Given that the magnitude and frequency of major dust storm events may change as a result of climate change impacts on drought and wind speed in Australia (CSIRO, 2007), there is a need to characterise the composition of this dust to increase our understanding of the implications of these dust events on humans, animals and the environment.

The primary aim of the current study was to investigate the microbiology and meteorology of two dust storms that passed over the southeast coast of Australia in April 2009. These dust events were forecast using a variety of criteria, confirmed using imagery from the Moderate Resolution Imaging Spectroradiometer (MODIS) satelliteborne sensor and meteorological observations, and characterised by large and intense cold fronts that entrained dust as they moved east across the continent. Dust and rain samples were collected during the storms, cultured, and the composition compared using polymerase chain reaction denaturing gradient gel electrophoresis (PCR-DGGE). Individual bands from the gel were isolated, purified and sequenced to identify members of the culturable microflora in the dust and rain samples.

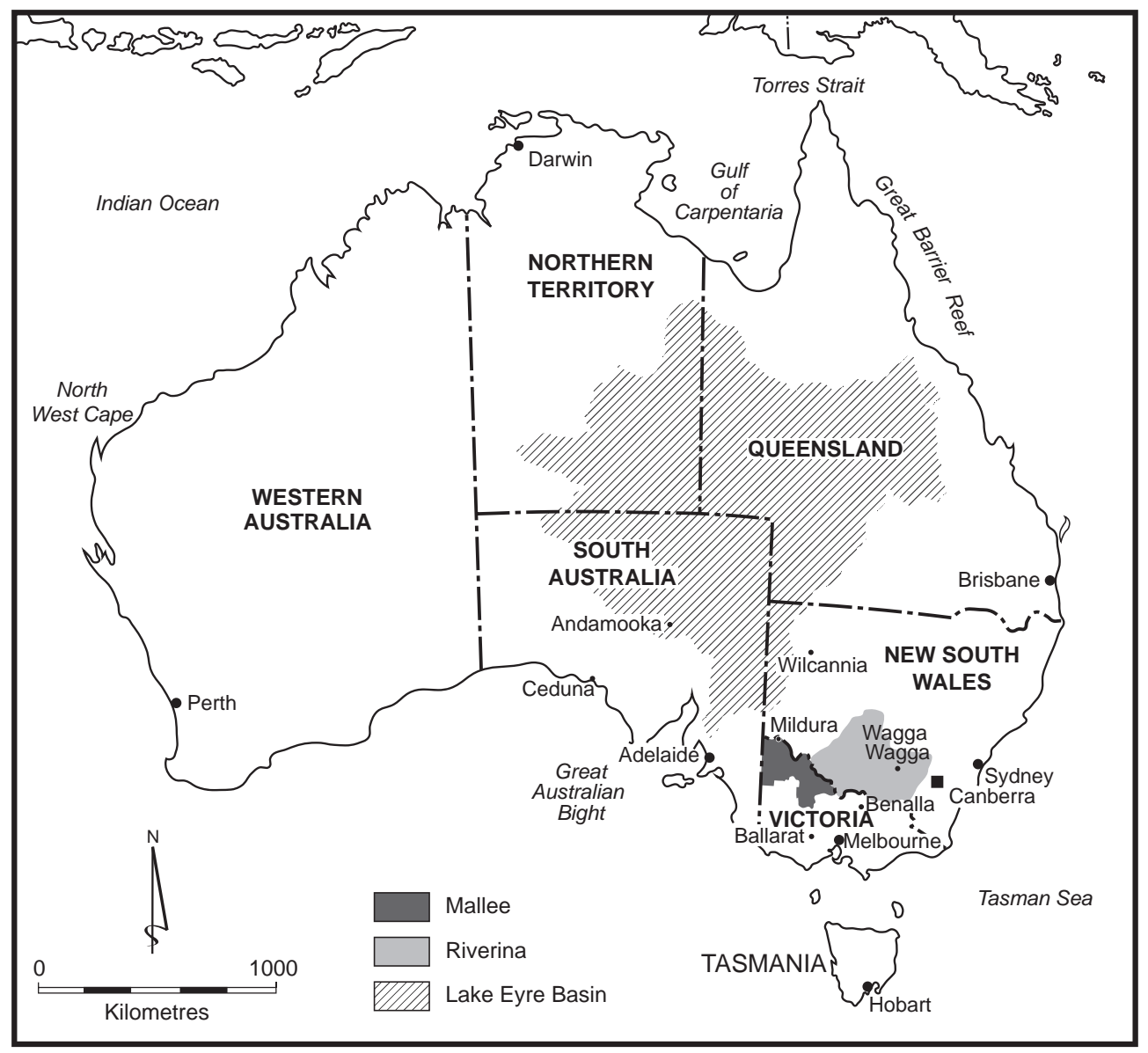

Fig. 1. Primary dust sources in Australia. The relative locations of the Lake Eyre Basin, Mallee and Riverina regions are indicated along with the locations from which meteorological observations of dust were recorded during DS15/4 and DS23/4. 


\section{Materials and methods}

\subsection{Meteorological analysis, sampling sites, and sampling}

The dust events were forecast 2-3 days prior to their occurrence on the basis of analysis of synoptic charts (available through the Bureau of Meteorology [BoM] at www.bom.gov.au), source locations and erodibility status (Leys et al., 2011). The forecasts and model outputs from the US dust storm forecasting model (Navy Aerosol Analysis and Prediction System, or NAAPS; http://www.nrlmry.navy.mil/aerosol) were analysed and potential dust plume trajectories at $500 \mathrm{~m}$ plotted using the Hybrid Single-Particle Lagrangian Integrated Trajectory (HYSPLIT) (Draxler and Hess, 1998; Draxler and Rolph, 2011). In Melbourne, a weather station operated by Monash University adjacent to the sampling site provided meteorological data. Meteorological observations for other locations were provided by the BoM. Dust entrainment was observed and confirmed with MODIS satellite-borne sensor and via meteorological observations from BoM stations. Based on the predicted start-time and paths of the events, sampling equipment was deployed in Canberra and/or Melbourne accordingly.

A description of the sampling sites is provided in Table 1. Air samples were collected during the two dust storms, 15th April 2009 (DS15/4) and 23rd to 26th April 2009 (DS23/4). At each sampling site in Canberra, a vacuum pump (AirChek XR500, SKC Inc.) collected air samples at a flow rate of $2.3 \mathrm{~L} / \mathrm{min}$ on sterile $0.2 \mu \mathrm{m}$-pore size cellulose nitrate membrane filters (Nalgene). Multiple samples were collected in Melbourne, $460 \mathrm{~km}$ southwest of Canberra (Fig. 1), utilising the same type of filters attached to vacuum pumps at a flow rate of $2.3 \mathrm{~L} / \mathrm{min}$ or $6.8 \mathrm{~L} / \mathrm{min}$. Where required after the dust events, the filters were stored at $4{ }^{\circ} \mathrm{C}$ until analysis. The filters were placed on tryptic soy agar (TSA, Difco) with the sample side up and incubated at room temperature in the dark for $48 \mathrm{~h}$ as specified by Griffin et al. (2001), and the number of bacterial colonies was determined. The microbial growth was aseptically scraped off the plate, inoculated into sterile TN150 buffer ( $10 \mathrm{mM}$ Tris- $\mathrm{HCl}, 150 \mathrm{mM} \mathrm{NaCl}, \mathrm{pH} 8$ ), and stored at $-80^{\circ} \mathrm{C}$.

Rainwater samples were collected during the DS23/4 dust event using autoclaved (Canberra) or ethanol (Melbourne) sterilised funnels and containers. The collecting container and funnel were changed every $24 \mathrm{~h}$ at the Canberra sampling sites, but a single container was used for all of

Table 1

Description of the sampling sites.

\begin{tabular}{|c|c|c|c|}
\hline Location & $\begin{array}{l}\text { Site }(\text { Abbreviation })^{\mathrm{a}} \text {, } \\
\text { coordinates and } \\
\text { altitude (MASL) }\end{array}$ & Classification & $\begin{array}{l}\text { Description of filter sampling at } \\
\text { each site }^{c}\end{array}$ \\
\hline \multirow[t]{5}{*}{ Canberra } & $\begin{array}{l}\text { Tuggeranong (K), } \\
35^{\circ} 2230 \mathrm{~S}, 149^{\circ} 03 \\
40 \text { E } 580 \mathrm{~m}\end{array}$ & Suburban & $\begin{array}{l}\text { Filters were positioned } 3 \mathrm{~m} \\
\text { above the ground. } 15 \mathrm{~km} \text { south } \\
\text { of the Canberra CBD }\end{array}$ \\
\hline & $\begin{array}{l}\text { Jaeger }(\mathrm{J}, \mathrm{JR}) 35^{\circ} 17 \\
03 \mathrm{~S}, 149^{\circ} 0653 \mathrm{E} \\
583 \mathrm{~m}\end{array}$ & Urban & $\begin{array}{l}\text { Filters were positioned on top } \\
\text { of the two storey Jaeger } \\
\text { building on The ANU Campus } \\
12 \mathrm{~m} \text { above the ground. } 1 \mathrm{~km} \\
\text { northwest of the Canberra CBD }\end{array}$ \\
\hline & Stromlo (S, SR) & \multirow[t]{3}{*}{ Rural } & \multirow{3}{*}{$\begin{array}{l}\text { Filters were positioned } 1.8 \mathrm{~m} \\
\text { above the ground at the ANU } \\
\text { seismic station. } 13 \mathrm{~km} \text { southwest } \\
\text { of Canberra CBD }\end{array}$} \\
\hline & $35^{\circ} 1908 \mathrm{~S} 148^{\circ} 59$ & & \\
\hline & 46 E $676 \mathrm{~m}$ & & \\
\hline \multirow[t]{5}{*}{ Melbourne } & Menzies (M, MR) & \multirow[t]{6}{*}{ Urban } & \multirow{6}{*}{$\begin{array}{l}\text { Filters were positioned on top } \\
\text { of a twelve storey building on } \\
\text { Monash University Campus } \\
40 \mathrm{~m} \text { above ground level. } \\
19 \mathrm{~km} \text { southeast of the } \\
\text { Melbourne CBD }\end{array}$} \\
\hline & $37^{\circ} 5447 \mathrm{~S} 145^{\circ} 07$ & & \\
\hline & 54 E $140 \mathrm{~m}$ & & \\
\hline & & & \\
\hline & & & \\
\hline & & & \\
\hline
\end{tabular}

\footnotetext{
a The single letter abbreviation refers to dust samples; the abbreviation plus "R" refers to rain samples.

b MASL - metres above sea level.

c $\mathrm{CBD}$ - central business district.
}

the days at the Melbourne site. The collected rainwater was passed through a filter that was processed as described above.

\subsection{DNA extraction from cultured environmental samples and PCR- $D G G E$}

DNA was extracted from the TN150 stock using the method of Walter et al. (2000) with the following modification. The frozen culture solution $(100 \mu \mathrm{L})$ was combined with $400 \mu \mathrm{L}$ of sterile TN150 and $0.3 \mathrm{~g}$ of sterile $0.1 \mathrm{~mm}$ zirconium-silica beads (Biospec Products), and the microorganisms were lysed by shaking for $3 \mathrm{~min}$ at $30 \mathrm{~Hz}$ in a tissue lyser (Qiagen). The DNA concentration was determined spectrophotometrically with a Nanodrop ND-1000 instrument (Thermo Scientific) and stored at $-20^{\circ} \mathrm{C}$.

PCR and DGGE were performed using HDA primers as previously described (Walter et al., 2000). These primers amplify the V2-V3 variable region, equivalent to positions 339-539 in the E. coli 16S rRNA gene (Tannock et al., 2000). Template DNA (100 ng) was amplified in a Cool Gradient Palm Cycler 9600 (Corbett Research) and the PCR products subjected to DGGE in a Bio-Rad DCode Universal Mutation Detection System (Bio-Rad). To standardise and compare band migration patterns among gels, a migration marker comprised of HDA PCR products from five species was run on each gel. All DGGE gels were analysed using BioNumerics version 5.10 software package (Applied Maths). Dendrograms were generated by performing cluster analysis using the Unweighted Pair Group Method using Arithmetic averages (UPGMA) and the Dice binary coefficient (with a $1 \%$ optimisation and $1 \%$ position tolerance). Bands that were identified to bacterial species were labelled in the software and their presence in each sample was determined.

DNA fragments of interest were excised from the gels using a sterile scalpel blade and stored at $4{ }^{\circ} \mathrm{C}$ until DNA extraction. DNA was extracted using the QIAEXII Gel Extraction Kit (Qiagen) as per an adapted protocol (Knarreborg et al., 2002); glass wool was not used. The eluted DNA was re-amplified using the HDA primers, and the mobility and purity of the PCR product was confirmed via DGGE. Fragments of interest were purified using Wizard® SV Gel and PCR Clean-Up System as recommended by the manufacturer (Promega) and sent to the Australian Genome Research Facility for sequencing according to the sample submission protocol (http://www.agrf.org.au). Sequences were analysed against the nonredundant nucleic acid database using BLAST (Zhang et al., 2000) accessed through the NCBI database (http://blast.ncbi.nlm.nih.gov/).

In one sample, the HDA PCR products were cloned into E. coli JM109 using the pGEM-T Vector System as recommended by the manufacturer (Promega). Individual white colonies were picked into $50 \mu \mathrm{L}$ sterile water, heated to $95^{\circ} \mathrm{C}$ for $10 \mathrm{~min}$, allowed to cool to room temperature, and then $2.5 \mu \mathrm{L}$ was used as template in a PCR reaction with SP6 and T7 primers utilising a PCR mix and similar protocol to that described for HDA primers except an annealing temperature of $45^{\circ} \mathrm{C}$ was used. PCR products of the expected size from successful transformants were purified and sent for sequencing as outlined above. All sequence data were then analysed using the Chromas Pro Version 1.41 software (Technelysium) and compared using BLAST as outlined above.

\section{Results}

\subsection{Meteorological analysis of the dust storms}

Sturman and Tapper (2006) provide a detailed summary of the typical kinematic and other characteristics of Australian cold fronts. DS15/4 and DS23/4 were both quite typical of summer/autumn frontal activity over south-central Australia, each with north to northwest winds ahead of the fronts and west to southeast flow behind the fronts. DS15/4 was associated with the passage of a pre-frontal trough and cold front anchored to a depression far south $\left(50^{\circ} \mathrm{S}\right)$ of southeast Australia (Fig. 2A). The northern tip of the front passed over the Mallee and Riverina regions of Victoria and central NSW, which in April 
2009 were highly erodible following years of drought and recent ploughing that was preparatory to the planting of grain crops. HYS PLIT analysis predicted that the dust plume would travel east (Fig. 2B) in the westerly flow behind this front. Due to the southerly position of the front in relation to the sources there was little prefrontal influence (for example the wind change associated with the front-trough system passed through Andamooka, in the north of South Australia, close to noon Central Standard Time (CST) on 14th April,

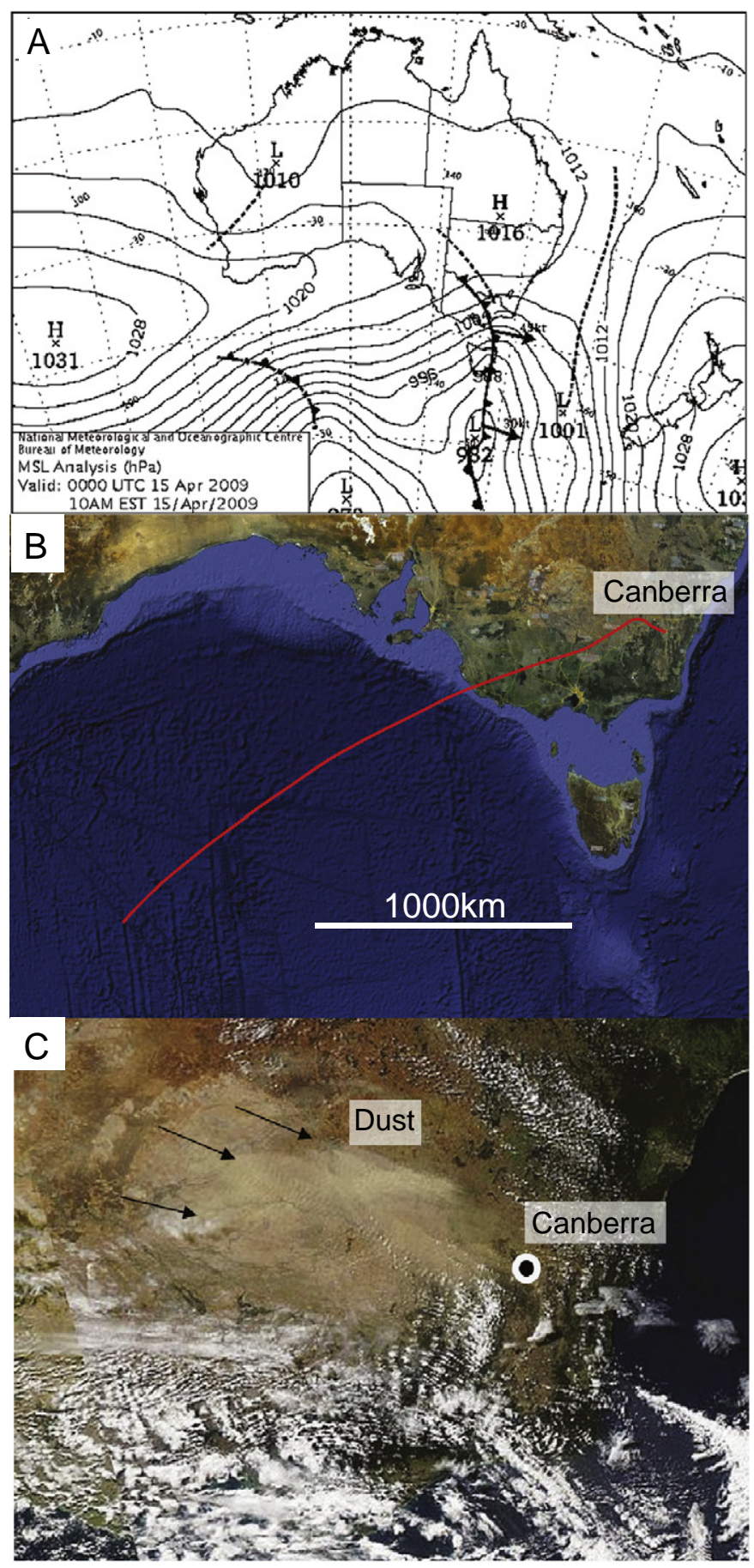

Fig. 2. Prediction and analysis of DS15/4. Panel A, Synoptic chart of the Mean Sea Level (MSL) Pressure Analysis on 15th April. The cold front (_ـ ) associated with entrainment of dust is indicated. Panel B, HYSPLIT back trajectories of air parcels arriving in Canberra at 9 am local time on the 15th April. Panel C, MODIS satellite image of the dust plume (direction indicated by arrows), confirming dust entrainment in central NSW about to reach Canberra (approx. $50-100 \mathrm{~km}$ from the eastern edge of the plume) on the afternoon of 15th April. and yet wind was reported as calm at 0900 CST on that day), but with the arrival of the front dust was entrained (mainly) from the MalleeRiverina area and travelled eastward towards Canberra as shown by the MODIS satellite imagery in Fig. 2C.

Analysis of observer records from BoM weather stations in the southeast quarter of the continent revealed that the first signs of dust for this event were seen on 14th April at Andamooka in the form of a severe dust storm (visibility $<200 \mathrm{~m}$ ). BoM observations for that station at 1500 CST also showed strong southerlies of $41 \mathrm{~km} / \mathrm{h}$ immediately behind the front. By 15th April, dust was being recorded throughout western NSW, the Mallee and Riverina regions despite the moderating westerly conditions behind the front (e.g. Wilcannia in northwest NSW reported west-southwest winds of $13 \mathrm{~km} / \mathrm{h}$ at both 0900 and 1500 Australian Eastern Standard Time [AEST]). At 0600 AEST suspended dust was seen in Ballarat in central Victoria, around $100 \mathrm{~km}$ west-northwest of Melbourne. By 0900 AEST suspended dust with visibility $<1 \mathrm{~km}$ in some areas was being recorded on both sides of the NSW-Victoria border from Mildura in the west to Benalla (167 km north-northeast of Melbourne) in the east. By 1200 AEST, the dust had progressed east to Wagga Wagga and by 1500 AEST the dust had reached Canberra. The first record of the event reaching the east coast was in Sydney at 2100 AEST in the form of a dust haze. Dust haze was seen continuously in Canberra until 1200 AEST the following day (16th April), with a few inland stations recording visibility reduced to

$<1 \mathrm{~km}$ throughout the day. By 1800 AEST on the 16th April the last of the dust was recorded in Sydney as it moved out over the Tasman Sea and travelled to New Zealand, over $2000 \mathrm{~km}$ away.

DS23/4 was a more active cold front anchored to a depression just off the South Australia-Victoria coast in the Great Australian Bight (Fig. 3A). The front reached far inland and the highly erodible Mallee and Riverina regions came under the influence of strong northwest pre-frontal winds followed by post-frontal west and southwest winds.

The first signs of dust entrainment for this event were recorded on 22nd April in pre-frontal northerly conditions at Ceduna on the south coast of South Australia, with dust progressively becoming more intense throughout the day and visibility reduced to $<1 \mathrm{~km}$ by 1500 AEST. Meteorological observations at Andamooka, $400 \mathrm{~km}$ northeast of Ceduna, showed north-northeast winds of $37 \mathrm{~km} / \mathrm{h}$ at 1500 AEST on the 22nd April. Pre-frontal northerly winds also dominated the 23rd April, with raised dust recorded along the South Australia NSW border. As the front moved progressively eastward into NSW during the night of the 23rd-24th April, raised dust was being recorded from eastern South Australia to central north NSW, with visibility decreasing to $<1 \mathrm{~km}$ at Wilcannia during the 24th as westerly winds increased to $33 \mathrm{~km} / \mathrm{h}$ by 1500 AEST. The dust progressed eastwards over NSW and out over the Tasman Sea during the night of the 24th-25th April. Satellite imagery showed the bulk of the plume out at sea on the 25th (data not shown). Extensive cloud cover made the detection of dust plumes in the satellite imagery difficult, but observers at ground stations were still recording dust entrainment in NSW throughout the 25th and 26th April.

Despite the presence of dust visible in the satellite imagery (Fig. 3C) and NAAPS (Fig. 4) as well as directional evidence from synoptic charts (Fig. 3A) and HYSPLIT analysis (Fig. 3B) that both Canberra and Melbourne received air that had passed over known dust sources, no observers on the ground at either location recorded dust. However both Canberra and Melbourne received rain on the last three days of sampling when there appears to have still been some dust in the atmosphere.

\subsection{Airborne bacterial concentration}

The number of viable bacteria varied among sites and storms (Fig. 5). Fungi were also present in the dust samples, but were not analysed in this study. Rainwater samples yielded confluent bacterial growth after incubation for $48 \mathrm{~h}$ (data not shown). 


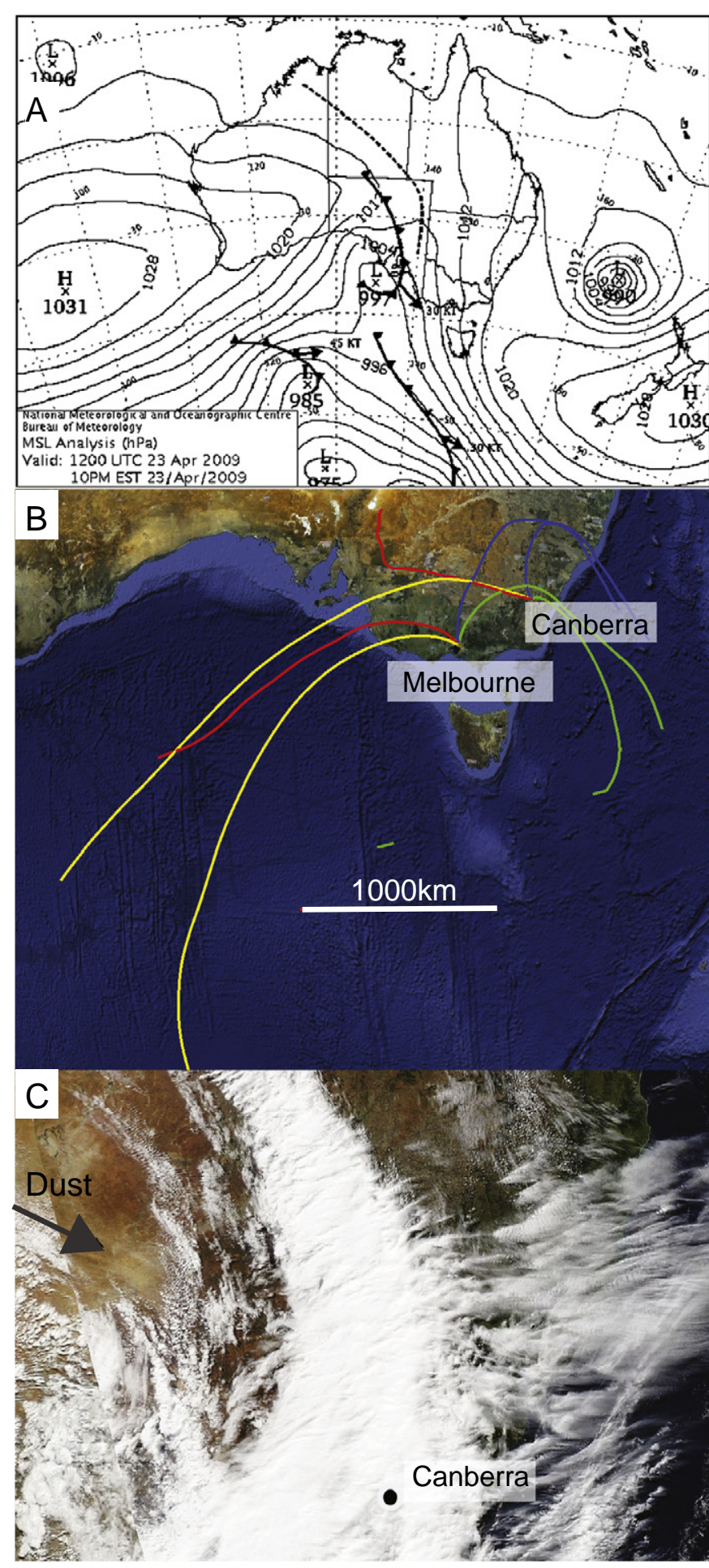

Fig. 3. Prediction and analysis of DS23/4. Panel A, Synoptic chart of the Mean Sea Level (MSL) Pressure Analysis on 23rd April. The cold front (_ـ $)$ associated with entrainment of dust is indicated. Panel B, HYSPLIT back trajectories of air parcels on and before this dust storm. Air parcels arriving in Canberra and Melbourne at 9 am local time on 23rd, 24th, 25th and 26th April are indicated by the green, blue, red and yellow lines, respectively. Panel C, MODIS satellite image showing dust entrainment in northern central NSW near Wilcannia on the afternoon of the 24th April approximately 700 km NW of Canberra.

\subsection{Bacterial community diversity and identity}

The composition of the culturable bacterial microflora of the aerosol and rain samples was compared using PCR-DGGE (Fig. 6). A number of bands were evident (average of 9 and 5 bands in dust and rain samples, respectively) indicating the presence of a diverse microflora in most samples. Comparison of the banding patterns indicated the presence of three main clusters: most dust samples from DS15/4 and DS23/4 were present within a large cluster; the rain samples collected in Canberra from Stromlo and Jaeger had a very different banding pattern and clustered separately from these dust samples; and JR1 and J4 formed a small separate cluster from the other samples. The single Melbourne rain sample that was left out over the four days of sampling for DS23/4 clustered together with the dust samples.

A number of bands were excised from the gel (Fig. 6), purified, identified and analysed across samples (Table 2). Three different phyla were represented among the identified bands (Fig. 7). Six of the thirteen bands represented members of the Firmicutes phylum; bands migrating at this position were found in multiple dust samples (Table 2). Five of these bands represented Bacillus, with three bands identified as Bacillus megaterium (Table 2, Fig. 6). Bands representing the Gamma and Beta Proteobacteria phyla were also identified in several rain and/or dust samples (Table 2). The dominant bands in the rain samples were identified as belonging to the Pseudomonas genus. To further investigate the species present, the PCR products amplified from SR2 (collected 26/4) were ligated into pGEM-T and cloned into E. coli. Eleven clones were sequenced: six were identified as P. fluorescens (99-100\% identity over 201 bases); three were identified as Pseudomonas fulva; one as Pseudomonas pseudoalcaligenes (99\% identity over 201 bases); and one as Pseudomonas species. These data support the DGGE profiles and suggest that multiple species of Pseudomonas were present in rain sample SR2.

\section{Discussion}

Samples were collected from two dust events in April 2009 that were characterised by large, intense cold fronts that entrained dust mainly from the Mallee and Riverina regions that were highly eroded, very dry from extended drought, and recently ploughed ahead of cropping. The dust travelled east in the first storm over Canberra, and east/southeast in the second storm over Canberra and Melbourne. Rain fell on both cities during the second dust storm. Our culture-dependent PCR-DGGE analyses of samples collected during the storms indicated that Australian dust and corresponding rain samples contained a diverse microflora. Multiple bands were evident on DGGE, and identification of several bands confirmed the presence of multiple genera and species representing three phyla. Numerous bands represented Bacillus species, and these were present in multiple dust samples collected from both Canberra and Melbourne. Interestingly, the microflora present in rain samples collected in Canberra during DS23/4 was quite different and the DGGE banding patterns from these samples clustered separately to most dust samples collected at the same time. Identification of several DGGE bands and PCR products from these rain samples indicated the presence of Pseudomonas species. In contrast to the rain samples collected in Canberra, the DGGE profile of the Melbourne rain and dust samples clustered together. This rain sample was left out for the duration of the sampling period during which the most competitive microbes could have grown in the mild temperatures (minimum and maximum temperatures in Melbourne over the four day dust storm varied between $8-23{ }^{\circ} \mathrm{C}$; data not shown).

While the meteorological analyses of the storms clearly indicated that dust reached Canberra for the DS15/4 event, visual confirmation (satellite and observers) was not as definitive for the DS23/4 event although clearly dust had been observed and recorded in NSW. There are several possible explanations for this: (a) the presence of most of the dust over the Tasman Sea on the morning of the 25th April indicates that the plume travelled over the targets overnight, at a time neither satellites nor observers could detect dust, and (b) rainfall was recorded at both sites from the 24th to the 26th April. As shown by O'Loingsigh et al. (2010), observers have a limited number of opportunities to record the weather. Each observed weather type is assigned a 

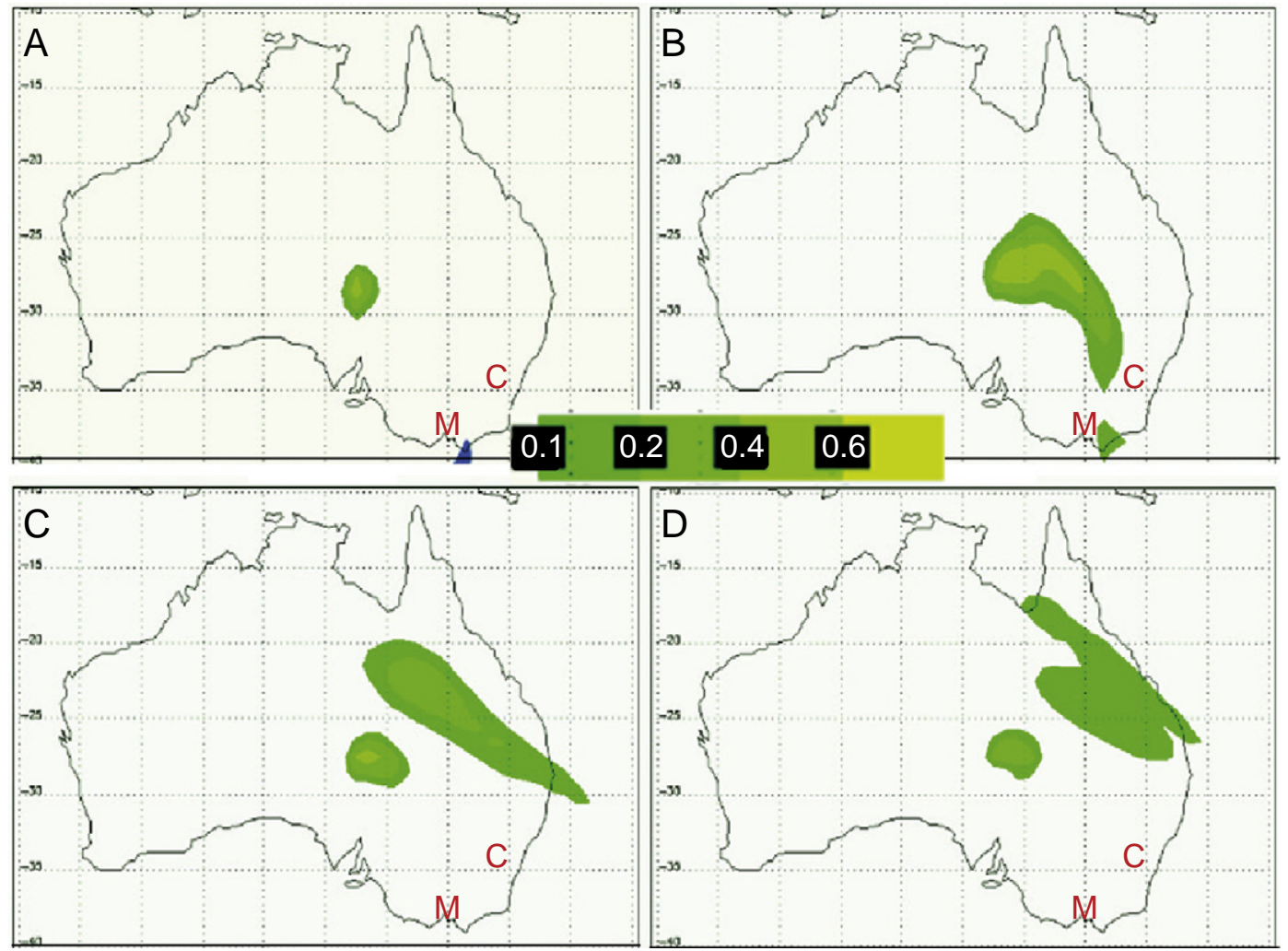

Fig. 4. NAAPS analysis of DS23/4. Dust surface concentration $\left(\mu \mathrm{g} / \mathrm{m}^{3}\right.$ ) reported by NAAPS at $0600 \mathrm{~h}$ on 23rd-26th April 2009 (Panels A though D, respectively) is indicated. The relative locations of Melbourne (M) and Canberra (C) are also represented.

precise code between 0-99, defined by the World Meteorological Organisation (WMO) and used at all weather stations across the world. Observations are made at 3-hourly intervals or less, during which time the weather can change. Unfortunately, observers can only record a single code per observation. As WMO protocol dictates that only the highestcoded weather type can be retained, dust codes often get superseded by higher-ranking moisture-related codes such as rain. Any observation of dust in Canberra or Melbourne between the 24th and the 26th April would have been superseded by observations of rain. However, based on the HYSPLIT (Fig. 3B) and NAAPS (Fig. 4) analysis it is not unreasonable to assume that some dust could have reached, or at least have been rained out, over Canberra and Melbourne. Microbiological data of dust

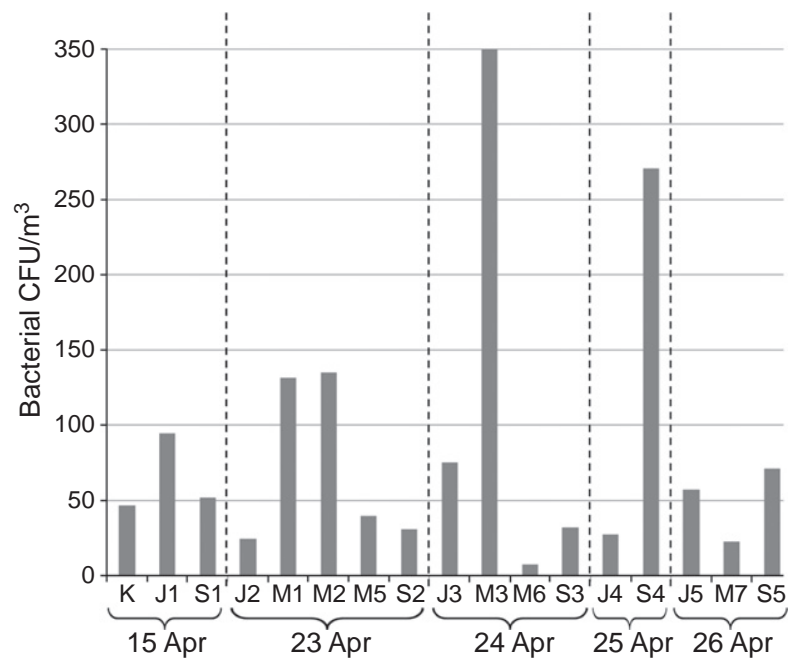

Fig. 5. Bacterial concentration in the dust samples collected during DS15/4 and DS23/4. The date of the samples, the location and sample number are indicated. samples potentially provides support for dust reaching Canberra and Melbourne for DS23/4 in three ways. First, the DGGE banding patterns for the dust samples collected at Stromlo (S) for DS15/4 and DS23/4 cluster together indicating similarity of the culturable microflora in these samples consistent with similar dust sources for both storms (Figs. 2C and 3C). The clustering of the DS15/4 and DS23/4 was most prominent for Stromlo possibly due to the fact that it is an urban site (Table 1) that may be more likely influenced by external (i.e. dust storm) rather than local disturbances. Second, several bands on DGGE were present in both storms, and present in samples isolated from both Melbourne and Canberra (Fig. 6 and Table 2). Third, the bacterial concentration of many dust samples collected for DS23/4 are of a similar magnitude or greater than those for 15/4 (Fig. 5).

The overall objective of this study was to obtain a snapshot of the culturable microflora of Australian rain and dust samples using PCRDGGE. Comparison of the DGGE profiles of the dust samples revealed some clustering based on sample site, suggesting there may be local influences on the microflora collected. As noted above, we were also able to detect differences in microflora composition between the Canberra rain and dust samples which was further characterised by isolating and identifying the DGGE bands. Sequencing of the DGGE bands revealed that different species can migrate to the same position (for example, Pseudomonas sp. and Pseudomonas putida, Table 2) and the same species can migrate to different positions on the gel (i.e. $B$. megaterium, Table 2). These issues with DGGE have been noted previously (Maki et al., 2008), and is likely due to the presence of multiple $16 \mathrm{~S}$ rRNA gene sequences within the bacterial genome (Dahllof et al., 2000), and is not exclusive to DGGE but will affect any microbial ecology technique based on this gene. We did attempt to extract and sequence DGGE bands in addition to those reported here, but were unable to isolate individual fragments. This was particularly problematic with bands closer to the top of the gel. This issue has previously been reported in the literature (Tannock et al., 2004) and is thought to result from the presence of background single stranded DNA migrating through 

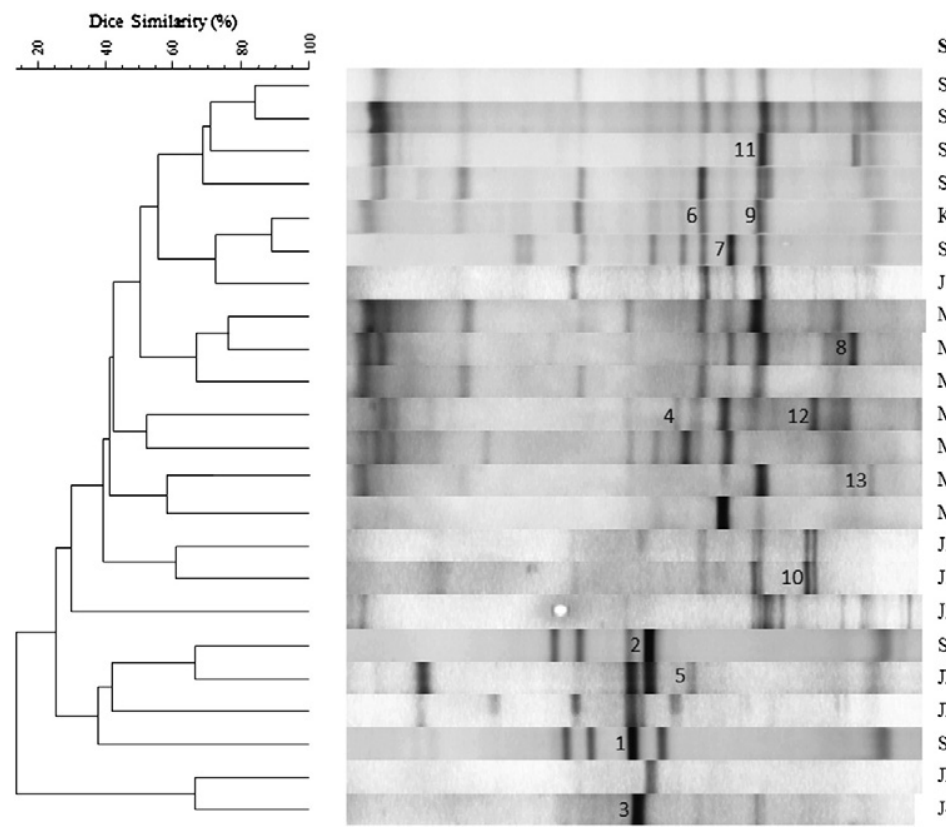

\begin{tabular}{lll}
\multicolumn{3}{l}{ Sample } \\
Date of collection & No. of bands \\
S1 & $15 / 04 / 09$ & 8 \\
S5 & $26 / 04 / 09$ & 11 \\
S2 & $23 / 04 / 09$ & 8 \\
S3 & $24 / 04 / 09$ & 11 \\
K & $15 / 04 / 09$ & 11 \\
S4 & $25 / 04 / 09$ & 9 \\
J1 & $15 / 04 / 09$ & 15 \\
M2 & $23 / 04 / 09$ & 10 \\
M6 & $24 / 04 / 09$ & 12 \\
M5 & $23 / 04 / 09$ & 9 \\
M1 & $23 / 04 / 09$ & 12 \\
M3 & $24 / 04 / 09$ & 11 \\
M7 & $26 / 04 / 09$ & 8 \\
MR & $23 / 04 / 09$ & 2 \\
J3 & $24 / 04 / 09$ & 7 \\
J5 & $26 / 04 / 09$ & 9 \\
J2 & $23 / 04 / 09$ & 13 \\
SR1 & $24 / 04 / 09$ & 5 \\
JR2 & $25 / 04 / 09$ & 8 \\
JR3 & $26 / 04 / 09$ & 10 \\
SR2 & $26 / 04 / 09$ & 5 \\
JR1 & $24 / 04 / 09$ & 1 \\
J4 & $25 / 04 / 09$ & 2 \\
& &
\end{tabular}

Fig. 6. PCR-DGGE analysis of the $16 \mathrm{~S}$ rRNA from cultured microbial communities in the dust and rain samples collected during DS15/4 and DS23/4. Sample identification, date of collection and number of bands detected in the BioNumerics analysis are indicated to the right of the gel lanes. Comparison of the fragmentation patterns using UPGMA and Dice similarity coefficient, as described in the Materials and Methods, is illustrated on the left. Bands that were excised, purified and identified are labelled (to the left) within the gel lane.

the gel. Consequently, we have conservatively interpreted the DGGE profiles.

The concentration of bacteria and the organisms identified from isolating and sequencing the DGGE bands are consistent with other reports in the literature on culturable dust microflora (Griffin et al., 2001; Griffin et al., 2003; Griffin et al., 2007; Maki et al., 2011; Polymenakou et al., 2008). Bacillus spp. were propagated and identified in all of these studies similar to our results where multiple DGGE bands representing Bacillus spp. were present in several dust samples from Canberra and Melbourne. These spore-forming organisms are common inhabitants of soil. While many members of this genus are harmless environmental organisms, several Bacillus species found in dust samples have been

Table 2

Identification and distribution of identified DGGE bands.

\begin{tabular}{|c|c|c|c|c|c|}
\hline \multirow[t]{2}{*}{ Band } & \multirow[t]{2}{*}{ Identification } & \multicolumn{2}{|c|}{$\begin{array}{l}\text { Sample type } \\
\text { in which band } \\
\text { of similar } \\
\text { migration } \\
\text { present (total } \\
\text { number of } \\
\text { this sample } \\
\text { type) }\end{array}$} & \multicolumn{2}{|c|}{$\begin{array}{l}\text { Sites from which band of similar } \\
\text { migration was present }\end{array}$} \\
\hline & & $\begin{array}{l}\text { Air } \\
(17)\end{array}$ & $\begin{array}{l}\text { Rain- } \\
\text { water } \\
(6)\end{array}$ & $\begin{array}{l}\text { Canberra (16 } \\
\text { samples total/3 } \\
\text { sites) }\end{array}$ & $\begin{array}{l}\text { Melbourne ( } 7 \\
\text { samples total) }\end{array}$ \\
\hline 1 & Pseudomonas sp. & 3 & 3 & $3 / 2$ & 3 \\
\hline 2 & Pseudomonas putida & 2 & 2 & $4 / 2$ & 0 \\
\hline 3 & Pseudomonas sp. & & & & \\
\hline 4 & Betaproteobacterium & 3 & 1 & $2 / 2$ & 2 \\
\hline 5 & $\begin{array}{l}\text { Uncultured } \\
\text { proteobacterium }\end{array}$ & 1 & 1 & $1 / 1$ & 1 \\
\hline 6 & Bacillus megaterium & 12 & 0 & $9 / 3$ & 3 \\
\hline 7 & Bacillus megaterium & 9 & 0 & $7 / 3$ & 2 \\
\hline 8 & Bacillus sp. & 14 & 1 & $11 / 3$ & 4 \\
\hline 9 & Bacillus megaterium & & & & \\
\hline 10 & Bacillus pumilus & 3 & 0 & $2 / 1$ & 1 \\
\hline 11 & Paenibacillus sp. & 6 & 0 & $4 / 2$ & 2 \\
\hline 12 & Enterobacter sp. & 4 & 0 & $3 / 2$ & 1 \\
\hline 13 & Enterobacter sp. & 6 & 1 & $6 / 2$ & 1 \\
\hline
\end{tabular}

implicated in human and plant disease (Bathily et al., 2010; From et al., 2007; Kellogg et al., 2004), justifying the interest in identifying these organisms found in dust endemic to different regions.

Our results also indicate that Pseudomonas were present in a few dust samples (Table 2), consistent with findings of other groups (Griffin et al., 2001; Griffin et al., 2003; Kakikawa et al., 2008). Pseudomonas sp., and Pseudomonas syringae in particular (Morris et al., 2008), has in recent years been implicated in forming ice nuclei and promoting subsequent rainfall. The traditional model of raindrop, hail and snow formation has been that minute inert particles such as mineral dust, soot and pollen are the agents that act as condensation nuclei. However, more recent work has shown the ubiquity of biological ice nucleators in snowfall (Christner et al., 2008a; Christner et al., 2008b) and that the life cycle (including propagation and spread) of Pseudomonas may be linked to its role in precipitation processes (Morris et al., 2008). Some frontal rain was associated with the passage of the April 2009 front-trough systems as they moved across the southeast of the continent. Although it is possible that some rainfall might have resulted from the formation of ice nuclei from mineral dust particles or associated biological particles, we have no evidence of this mechanism operating in this case. Work to establish such links is well beyond the scope of this paper.

Pseudomonas has been cultured from rain in Newcastle, NSW (Evans et al., 2006; located $160 \mathrm{~km}$ northeast of Sydney on the coast) and rain water tanks at twenty two sites distributed from Melbourne to Brisbane (Evans et al., 2009). Evans et al. (2006) investigated the relationship among rain microflora (bacterial numbers, types of organisms cultured) and meteorological/climatic parameters (wind velocity, wind direction, and dry interval). These authors found that Pseudomonas concentrations were greatest in events under north to northwest wind influences, suggesting an inland source location relative to the sampling site. When sampling rain water tanks, Pseudomonas spp. were found in $58 \%$ of samples (80 samples from 22 tanks analysed in total), with Pseudomonas putida, $P$. fluorescens and Pseudomonas lanceolata being the most prevalent species identified (Evans et al., 2009). Of interest, Bacillus was also commonly isolated ( $42 \%$ of samples), with members of the Bacillus cereus group being most common, although other species were identified including B. pumilis. In general, Evans et al. (2009) concluded that a diverse culturable microflora was present in the rainwater tanks that 


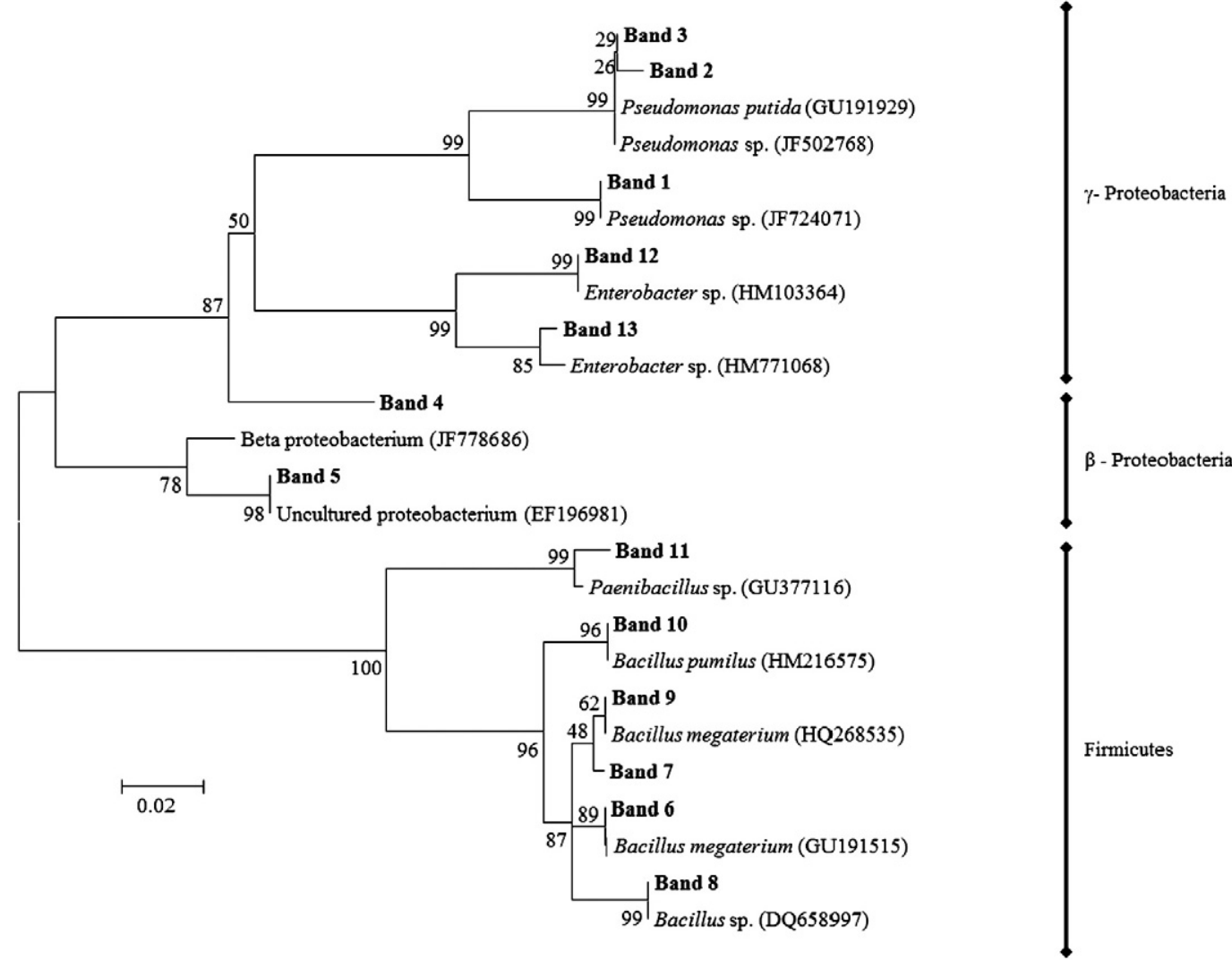

Fig. 7. Identification of bands purified from the gels using $16 \mathrm{~S}$ rRNA phylogenetic reconstruction of sequences from isolated bands and nearest BLAST matches (Genbank accession numbers are provided in parentheses). Reconstruction was performed using the Neighbour Joining method and 10,000 bootstrap replicates. The percentage of replicate trees in which the associated taxa clustered together in the bootstrap is shown next to the branches.

were sampled. Other organisms identified in their study and our study (refer to Table 2) included Enterobacter, Paenabacillus, and Proteobacteria. Collectively, our data and that of Evans et al. (2009) suggest that water quality from tanks could be influenced by major dust events. This is significant considering that the installation of rainwater tanks has been actively promoted throughout Australia during the recent drought to supplement water sources, and to improve water security and urban liveability under climate change (Tapper, 2011; Wong et al., 2011).

Not surprisingly, our culture-based results were not entirely consistent with the culture-independent (16S rRNA E. coli clone library) results obtained from Australian dust reported by De Deckker et al. (2008). This study found a much wider range of phyla present in their dust sample, which would be expected in the absence of bias introduced by culturing. Apart from both studies identifying members of Firmicutes (with De Deckker et al., 2008 reporting few clones identified as Bacillus spp.), there are few similarities in the phyla, genera and species. This is consistent with few clones being sequenced in this study (48 clones) combined with the estimate that the culturable component of soil samples is likely to represent $1-10 \%$ of the total microflora present. Undoubtedly, application of culture-independent high-throughput approaches to the characterisation of the microflora in aerosols, dust and rain are needed to reveal the full complexity of the atmospheric microflora and possibly reveal dust source-specific bacteria that can be used to track storms. We are currently applying this approach to characterising Australian dust samples.

\section{Conclusions}

With the recent drought in Australia, there has been an increase in the magnitude and frequency of major dust events (CSIRO, 2007) motivating the current investigation of the two dust storms in April 2009.
The samples collected during the dust event had a diverse culturable flora revealed by PCR-DGGE with several dust samples containing Bacillus spp., and rain samples collected in Canberra contained multiple species of Pseudomonas, which are known to be involved in ice nucleation and rain formation. Additionally, the bacteria identified in our study are similar to those identified in Australian rain (Evans et al., 2006) and rain water tanks (Evans et al., 2009), highlighting the possibility that dust storms and rain associated with dust storms could affect water quality in rain tanks and the environment as a whole. This also raises the intriguing possibility that different air mass trajectories towards eastern Australian cities may enhance precipitation processes, depending on their relative entrainment of microbiological nuclei.

\section{Acknowledgements}

The research presented in this study was supported by an Australian Research Grant Discovery Project DP0772180.

\section{References}

Bathily H, Babana AH, Samaké F. Bacillus pumilus, a new pathogen on potato tubers in storage in Mali. Afr J Microbiol Res 2010;4:2067-71.

Christner B, Morris C, Foreman C, Cai R, Sands D. Ubiquity of biological ice nucleators in snowfall. Sci News 2008a;319:1214.

Christner B, Cai R, Morris C, McCarter K, Foreman C, Skidmore M, et al. Geographic, seasonal, and precipitation chemistry influence on the abundance and activity of biological ice nucleators in rain and snow. Proc Natl Acad Sci U S A 2008b;105:18854-9.

CSIRO. Climate change in Australia technical report9781921232947; 2007http://www. climatechangeinaustralia.gov.au. pp. 148.

Dahllof I, Baillie H, Kjelleberg S. rpoB-based microbial community analysis avoids limitations inherent in 16S rRNA gene intraspecies heterogeneity. Appl Environ Microbiol 2000;66:3376-80.

De Deckker P, Abed RMM, de Beer D, Hinrichs K-U, O'Loingsigh T, Schefuß E, et al. Geochemical and microbiological fingerprinting of airborne dust that fell in Canberra, Australia, in October 2002. Geochem Geophys Geosyst 2008;9:Q12Q10. 
Draxler RR, Hess GD. An overview of the HYSPLIT 4 modeling system of trajectories, dispersion, and deposition. Aust Meteorol Mag 1998;47:295-308.

Draxler RR, Rolph GD. HYSPLIT (HYbrid Single-Particle Lagrangian Integrated Trajectory). Model access via NOAA ARL READY Website http://ready.arl.noaa.gov/HYSPLIT.php. Silver Spring, MD: NOAA Air Resources Laboratory; 2011.

Evans CA, Coombes PJ, Dunstan RH. Wind, rain and bacteria: the effect of weather on the microbial composition of roof-harvested rainwater. Water Res 2006;40:37-44.

Evans CA, Coombes PJ, Dunstan RH, Harrison T. Extensive bacterial diversity indicates the potential operation of a dynamic micro-ecology within domestic rainwater storage systems. Sci Total Environ 2009;407:5206-15.

From C, Hormazabal V, Hardy SP, Granum PE. Cytotoxicity in Bacillus mojavensis is abolished following loss of surfactin synthesis: implications for assessment of toxicity and food poisoning potential. Int J Food Microbiol 2007;117:43-9.

Garrison VH, Shinn EA, Foreman WT, Griffin DW, Holmes CW, Kellogg CA, et al. African and Asian dust: from desert soils to coral reefs. Bioscience 2003:53:469-80.

Griffin DW, Kellogg CA. Dust storms and their impact on ocean and human health: dust in earth's atmosphere. Ecohealth 2004;1:284-95.

Griffin D, Garrison V, Herman J, Shinn E. African desert dust in the Caribbean atmosphere: microbiology and public health. Aerobiologia 2001;17:203-13.

Griffin DW, Kellogg CA, Garrison VH, Lisle JT, Borden TC, Shinn EA. Atmospheric microbiology in the northern Caribbean during African dust events. Aerobiologia 2003;19:143-57.

Griffin DW, Kubilay N, Koçak M, Gray MA, Borden TC, Shinn EA. Airborne desert dust and aeromicrobiology over the Turkish Mediterranean coastline. Atmos Environ 2007; 41:4050-62.

Hua N-P, Kobayashi F, Iwasaka Y, Shi G-Y, Naganuma T. Detailed identification of desert-originated bacteria carried by Asian dust storms to Japan. Aerobiologia 2007;23:291-8

Kakikawa M, Kobayashi F, Maki T, Yamada M, Higashi T, Chen B, et al. Dustborne microorganisms in the atmosphere over an Asian dust source region, Dunhuang. Air Qual Atmos Health 2008;1:195-202.

Kellogg CA, Griffin DW. Aerobiology and the global transport of desert dust. Trends Ecol Evol 2006;21:638-44.

Kellogg CA, Griffin DW, Garrison VH, Peak KK, Royall N, Smith RR, et al. Characterization of aerosolized bacteria and fungi from desert dust events in Mali, West Africa. Aerobiologia 2004;20:99-110

Knarreborg A, Simon MA, Engberg RM, Jensen BB, Tannock GW. Effects of dietary fat source and subtherapeutic levels of antibiotic on the bacterial community in the ileum of broiler chickens at various ages. Appl Environ Microbiol 2002;68:5918-24.

Leys JF, Heidenreich SK, Strong CL, G.H. M, Quigley S, Yamada M, et al. PM10 concentrations and mass transport during "Red Dawn" - Sydney, 23 September 2009. Aeolian Res 2011;3:327-42.

Maki T, Susuki S, Kobayashi F, Kakikawa M, Yamada M, Higashi T, et al. Phylogenetic diversity and vertical distribution of a halobacterial community in the atmosphere of an Asian dust (KOSA) source region, Dunhuang City. Air Qual Atmos Health 2008;1:81-9.

Maki T, Susuki S, Kobayashi F, Kakikawa M, Tobo Y, Yamada M, et al. Phylogenetic analysis of atmospheric halotolerant bacterial communities at high altitude in an Asian dust (KOSA) arrival region, Suzu City. Sci Total Environ 2010;408:4556-62.
Maki T, Aoki K, Kobayashi F, Kakikawa M, Tobo Y, Matsuki A, et al. Characterization of halotolerant and oligotrophic bacterial communities in Asian desert dust (KOSA) bioaerosol accumulated in layers of snow on Mount Tateyama, Central Japan. Aerobiologia 2011. doi:10.1007/s10453-011-9196-0.

McTainsh G, Strong C. The role of aeolian dust in ecosystems. Geomorphology 2007;89: 39-54.

McTainsh G, Chan Y-C, McGowan H, Leys J, Tews K. The 23rd October 2002 dust storm in eastern Australia: characteristics and meteorological conditions. Atmos Environ 2005;39:1227-36.

Morris C, Sands D, Vinatzer B, Glaux C, Guilbaud C, Buffière A, et al. The life history of the plant pathogen Pseudomonas syringae is linked to the water cycle. ISME J 2008;2:321-34

O'Loingsigh T, McTainsh GH, Tapper NJ, Shinkfield P. Lost in code: a critical analysis of using meteorological data for wind erosion monitoring. Aeol Res 2010;2:49-57.

Polymenakou PN, Mandalakis M, Stephanou EG, Tselepides A. Particle size distribution of airborne microorganisms and pathogens during an intense African dust event in the eastern Mediterranean. Environ Health Perspect 2008;116:292-6.

Shao Y, Wyrwoll K-H, Chappell A, Huang J, Lin Z, McTainsh GH, et al. Dust cycle: an emerging core theme in Earth system science. Aeol Res 2011;2:181-204.

Shinn EA, Smith GW, Prospero JM, Betzer P, Hayes ML, Garrison V, et al. African dust and the demise of Caribbean coral reefs. Geophys Res Lett 2000;27:3029-32.

Sturman AP, Tapper NJ. The Weather and Climate of Australia and New Zealand. Melbourne: Oxford University Press; 2006.

Tanaka TY, Chiba M. A numerical study of the contributions of dust source regions to the global dust budget. Global Planet Change 2006;52:88-104.

Tannock GW, Munro K, Harmsen HJM, Welling GW, Smart J, Gopal PK. Analysis of the fecal microflora of human subjects consuming a probiotic product containing Lactobacillus rhamnosus DR20. Appl Environ Microbiol 2000;66:2578-88.

Tannock GW, Munro K, Bibiloni R, Simon MA, Hargreaves P, Gopal P, et al. Impact of consumption of oligosaccharide-containing biscuits on the fecal microbiota of humans. Appl Environ Microbiol 2004;70:2129-36.

Tapper N. Climate change, urban climate and human health: some recent research perspectives from Australia. Urban Futures and Human and Ecosystem Wellbeing. Paris: UNESCO; 2011.

Walter J, Tannock GW, Tilsala-Timisjarvi A, Rodtong S, Loach DM, Munro K, et al. Detection and identification of gastrointestinal Lactobacillus species by using denaturing gradient gel electrophoresis and species-specific PCR primers. Appl Environ Microbiol 2000;66: 297-303.

Wong THF, Allen R, Beringer J, Brown RR, Chaudhri V, Deletic A, et al. Stormwater management in a Water Sensitive City: Blueprint 2011. In: Wong THF, editor. The Centre for Water Sensitive Cities, Clayton, VIC; 2011. p. 46.

Zhang Z, Schwartz S, Wagner L, Miller W. A greedy algorithm for aligning DNA sequences. J Comput Biol 2000; 7:203-14. 